\title{
MATTER
}

\section{Review of the book: Space after Deleuze (Saldanha, 2017)}

\section{Paula Estalayo Bielsa \\ University of Barcelona}

\section{Received: 16/10/2019}

Accepted: 25/01/2020

\section{DOI: https://doi.org/10.1344/jnmr.v111.29386}

Space after Deleuze is an entrance to Deleuze's thinking focusing specially on the concept of space. The author's objective is to show that Deleuze's work is geographical and that it provides "one of the best philosophical resources for continuing and refining the project of giving a dynamic thickness to space" (p. 3). Thus, Arun Saldanha invites us to open the possibilities for thinking that Deleuzian space brings to a contemporary political project due to four main reasons. First, "space encompasses not only urban space and other landscapes [but also] cosmic spatiality of physics [and] its heterogeneous, intensive, and embodied workings." (p. 2). Second, space entails an ethical consideration entangled with the world's own going; that is to say, actively changing, the coming of the world is triggered by the ethical dimension of space itself. Thirdly, $A$ Thousand Plateaus has been widely explored via the concepts of "assemblage", "rhizome", or "becoming", but less so via the concept of space. And, fourth, space is real, material and far from Kantian assumptions. In Saldanha's words, it "is difference, multiplicity, change and movement, not some separate formal realm that would frame them" (p. 3).

The first chapter, Earth, situates Deleuze within a long tradition of continental philosophy that covers from Plato to Descartes. Within this genealogy of thought, Saldanha locates Deleuze between Kantian immanence and Copernican radicality of de-centering the human subject. Deleuze's ontological project is defined as "geophilosophy", that is, "the creation of concepts as more-than-human and emergent 
from "the earth" (p. 13). In other words, it seeks to generate new concepts; that is, the iteration of the process of thinking itself as "radically open and undetermined" ( $p$. 12). Geophilosophy then, is a topological and critical approach that provides lines of flight to apply an "earthly politics" (p. 33) according to the needs of the entanglement between researcher and research, situated within the Anthropocene era.

Our current moment, defined as the Anthropocene, is understood by Saldanha as the collapse or the self-destruction of the capitalist system. Therefore, the Anthropocene, climate change, and the current crises of the planet force us to rethink the different temporal space layers of globalization, in a more-than-human way. These realities require rethinking the Earth but not as a deconstructive move, but rather as "creat[ing] and multipl[ying] 'smoother spaces' within the geographies of capitalism" (p. 43).

Deleuze identifies a clear political dimension in the creation of concepts because they must produce non-capitalist environments and collectives (Deleuze \& Guattari, 1991 in Saldanha, 2017). Philosophy serves to create a new world, a different globalization. Thus, understanding critically this global phenomenon is achieved through a notion of space that emphasizes interdependencies and inequality between places, and denounces the provincialisms that perpetuate these inequalities. A new Earth and new people are required, which is not based on the principles of the neoliberal democratic system.

In chapter two, Flows, Saldanha explores the relationship between flows and society (understood this last one as population, war and capitalism) (p. 104) through a Deleuzian geographical analysis. This allows to explore how they understand politics (breaking through molar and molecular as binary oppositions) and ethics. These interactions are materialized through "flux" is the "basis of how a Deleuzian ontology of population, committed to ethics and inseparable from politics. Deleuze's political project wonders about how difference is distributed in an unfair way, and reconfigures not only the flows and desires of capitalism, but also social structures.

Capital is central to Deleuze's thinking. He argues that there is only one world, the world of capital, "which is internally split and re-split as insecurities multiply" (p.87). 
The political economy of Deleuze and Guattari understands how capital penetrates other flows and meanings, and it is the axiom that rules in production, circulation, but also in subjectivation and politics. In their political economy, deterritorialization maintains the comprehension and expansion of money as fundamental in the modifications of the earth's crust. Successive movements of deterritorialization create new reterritorializations that lead to the accumulation of capital: "Something is deterritorialized only to be reterritorialized within a new configuration" (p. 113).

For Deleuze and Guattari, "it makes no sense to analyze the geography of money without analyzing the strata of the unconscious and everyday spaces through which money can flow and bodies are enslaved" (p.82). Nevertheless, at the same time, these bodies organize as well physical geographies (molar differences like class, race or gender) since "Deleuzian control happens [...] not only upon bodies but through bodies." (p. 90). If Deleuzian control happens through bodies, the main political problem of the flow is to think "how people could undercut law and state altogether [...]" (p. 65). Deleuze and Guattari were interested in what exceeds these territorializations of capital, what happens in the margins and in the periphery such as the ghettos, the combat, the war machine, and in nomadism.

The framework exploring how human beings build their geographies is presented in chapter three, Places. This chapter is particularly important for feminist contemporary theory and politics since it gives us an entry to think the concept of identity otherwise. Deleuze and Guattari and critical geographers agree in stating that movement and desire are prior to the human "and hence constitute place and identity." (p. 105). That is, identities are conformed by movement, desires and spatiotemporalities even before the human being is presented. That is to say, identities (politically speaking) are affective flows, or as Felicity Colman (2010), "affective selves". For Deleuze, any territory or place comes from the interaction of bodies with the environment, matter and energy, and the process by which something is temporarily stabilized, regulating these flows of matter and energy, what he calls territorialization. Therefore, places are constituted and transformed with the movements of bodies and technologies, and are always reassembled. 
Besides, this chapter also provides the key elements to understand a methodological approach that engages with Deleuzian theory. the creation of places serves to scale bodies because they are affected (in the Spinozian sense) by nature. The ability of a body to act continually changes in the encounter with other bodies and with certain circumstances. So, the important thing about an encounter is what the body is allowed to do. If bodies must be understood within their environment, in our days this means within capitalism. Therefore, Deleuze wonders about what bodies can do to combat capitalism. It is through the space-time functioning of affection, through chains of bodily interconnections, that societies are constituted. Basing himself on this premise, Saldanha shows us how a fundamental ontology of space helps us rethink the city since "to understand the difficulty of urban life is to understand human nature" (p.153).

That is why Saldanha finishes the chapter defining the concept of cities, which is particularly important for postcolonial theory, feminist theories, and urban studies in general. To begin with, he relates the concept of the city with the plane (so wellknown in Deleuzian studies), pointing at how immanence is "a bottom-line of any manner of thinking" (p. 144). Neverthless, what seems more important from a new materialist theorization of space itself is the concept of "ghetto" since it implies two complementary things fro identity politics and for onto-epistemologies themselves. On the one hand, is how Deleuze and Guattari "talk about the self-segregation of political identities" (p. 156). This is directly related to the economic-cultural-wasteful surplus that capitalism creates within cities. These "ghettos" are "anyspaceswhatever" (p. 161) and they are continuously becoming together with the bodies concluding in an entanglement of the city and the body that re-defines both concepts and pursues the monist univocity so present in new materialisms. In Shaldanha's words, "The city is not a static background of life but actively implicated or enfolded into the capacities of bodies."

This explanation demonstrates how pertinent and relevant is Deleuzian theory to understand migratory flows, environmental diseases, fascist regimes, etc. since all partaking bodies in a specific phenomenon are always going to be subjected to the 
spatiality of the city, which at the same time, is a permanent movement between what bodies can do and a permanent space-time affection that moves and deterritorializes established landscapes in our cultural and political horizons since the city is an active part of the development of any identity.

In the last chapter, Maps, Saldanha explores how Deleuze develops the affective dimensions of the map or diagram, and explains the Deleuzian ontological turn created during the mapping procedure. The hegemonic mapping is based on a representationalist epistemology from resemblance and reproducibility. On the contrary, the Deleuzian map participates in the reality that needs to be mapped. Besides, it is in this chapter where Shaldanha explores the concept of cartography, which was part of the title of one of the foundational new materialist texts: New Materialism: Interviews and Cartographies (Dolphijn \& van der Tuin, 2012). Cartography is defined as "non-representational, a corporeal and critical practice. Instead of a representation with a fixed scale, catalogue number and predetermined use. (p. 194), providing the key to understanding methodologies in a materialist sense.

The chapter ends with the philosopher's thought about time, that is in the essence of cartography. Space is dynamic in an inevitably way, and hence inextricable from time. Time is continually assembled out of syntheses, that is, it only exists within the processes of events taking place (p. 206). From this book we can see Deleuze as a materialist thinker. With him, we can think space "as material differences distributed unevenly, interpenetrating at various scales and determined by changing virtual dimensions" (p.184). This provides a differing entry point to understand Deleuze in what I would consider a new materialist methodological approach. As Saldanha (p. 185) points out, "Deleuzian Ideas are problems that demand solutions by the material system they inhabit but are never fully answered." In his book, Shaldanha provides multiple definitions for differing concepts of Deleuze, covering almost the totality that any Deleuzian dictionary would cover but following a single entry point, that is space. He finishes the book without conclusions only to follow this type of methodology. "Problems are changed a little every time they are solved. [...] Problems are not 
simply constraints but "spaces of possibility"' (ibid.) Precisely this is what the book offers us a space of possibility to think feminist materialist politics otherwise, to look for processes and for those differing patters that provide acts of resistance.

\section{Bibliography}

Colman, Felicity (2010). Affective self: Feminist Thinking and Feminist Actions. Contemporary French and Francophone Studies. 14 (5): 543 - 552

Saldanha, Arun (2017). Space After Deleuze. 1st Edition. Bloomsbury Academic. 2017; 219pp.: 978-1-4411-1188-3 (HB) 